\title{
BRCA1 and BRCA2 point mutations and large rearrangements in breast and ovarian cancer families in Northern Poland
}

\author{
MAGDALENA RATAJSKA ${ }^{1}$, IZABELA BROZEK ${ }^{1,2}$, ELZBIETA SENKUS-KONEFKA ${ }^{3}$, JACEK JASSEM ${ }^{3}$, \\ MAGDALENA STEPNOWSKA ${ }^{1}$, GRAZIA PALOMBA ${ }^{4}$, MARINA PISANO $^{4}$, MILENA CASULA $^{4}$, \\ GIUSEPPE PALMIERI ${ }^{4}$, AKE BORG ${ }^{5}$ and JANUSZ LIMON ${ }^{1}$ \\ ${ }^{1}$ Department of Biology and Genetics, Medical University of Gdansk, Debinki 1, 80-210; \\ ${ }^{2}$ Regional Oncological Outpatient Clinic, Sklodowskiej-Curie 2, 80-210; ${ }^{3}$ Department of Oncology and \\ Radiotherapy, Medical University of Gdansk, Debinki 7, 80-211 Gdansk, Poland; ${ }^{4}$ Institute of Biomolecular \\ Chemistry - Section of Sassari, National Research Council (C.N.R.), Alghero, Traversa La Crucca, 3 - Reg. Baldinca, \\ 07040 Li Punti-Sassari (SS), Italy; ${ }^{5}$ Department of Oncology, Lund University, SE-221 85 Lund, Sweden
}

Received July 26, 2007; Accepted August 28, 2007

\begin{abstract}
Sixty-four Polish families with a history of breast and/or ovarian cancer were screened for mutations in the BRCA1/2 genes using a combination of denaturing high performance liquid chromatography (DHPLC) and sequencing. Two thirds $(43 / 64 ; 67 \%)$ of the families were found to carry deleterious mutations, of which the most frequent were BRCA1 5382insC $(n=22 / 43 ; 51 \%)$ and Cys61Gly $(n=9 / 43$; $20 \%$ ). Two other recurrent mutations were BRCA1 185delAG $(n=3)$ and 3819del5 $(n=4)$, together accounting for $16 \%$ of the 43 mutation-positive cases. We also found three novel mutations (BRCA1 2991del5, BRCA2 6238ins2del21 and 8876delC) which combined with findings from our earlier study of 60 Northern Polish families. Moreover, screening of 43 BRCA1/2 negative families for the presence of large rearrangements by multiplex ligation-dependent probe amplification (MLPA) resulted in the finding of two additional BRCA1 mutations: a deletion of exons $1 \mathrm{~A}, 1 \mathrm{~B}$ and 2, and a deletion of exons 17-19, both present in single families. We conclude that the Polish population has a diverse mutation spectrum influenced by strong founder effects. However, families with strong breast/ovarian cancer history who are negative for these common mutations should be offered a complete BRCA gene screening, including MLPA analysis.
\end{abstract}

\section{Introduction}

About $5-10 \%$ of all breast cancer cases are associated with a strong genetic predisposition and highly penetrant autosomal

Correspondence to: Dr Janusz Limon, Department of Biology and Genetics, Medical University of Gdansk, Debinki 1, 80-210 Gdansk, Poland

E-mail: jlimon@amg.gda.pl

Key words: breast cancer, ovarian cancer, BRCA1, BRCA2, multiplex ligation-dependent probe amplification dominant trait. Two major breast cancer susceptibility genes, BRCA1 and BRCA2, have been identified. To date, more than 3000 different sequence variants have been described in these genes. Many of them are disease-associated, but also included are unclassified variants and polymorphisms (1). The majority of deleterious mutations are frame-shift or nonsense mutations that result in premature translation termination and are localised throughout the genes, but splice-site mutations as well as single amino acid substitutions (missense mutations) in functionally important and well-defined domains also occur. Traditionally, mutation screening entails the use of methods such as the protein truncation test, denaturing high performance liquid chromatography (DHPLC), single strand conformational polymorphism analysis, as well as direct sequencing of the coding and short flanking intronic regions to pinpoint the mutation. One of the shortcomings of this traditional approach is that large rearrangements may be overlooked. Indeed, it has been suggested that as much as $30 \%$ of mutations in the BRCA1 gene are missed by standard mutation detection methods (2). Consequently, a proportion of the families that initially test negative for BRCA1 and BRCA2 mutations are likely to harbour cryptic mutations undetectable by conventional PCR-based methods.

The aim of this study was to evaluate the prevalence and spectrum of BRCA1/2 point mutations and large deletions/ duplications in breast cancer families from Northern Poland. Our additional aim was to elaborate the genetic testing strategy for Polish breast and/or ovarian cancer families.

\section{Materials and methods}

The study comprises 124 families with clustering of breast and/or ovarian cancer who were referred to our department for oncogenetic counselling between 1999 and 2004 and who met one of the following criteria: i) three first or second degree relatives (from one parental side of the family) with breast or ovarian cancer diagnosed at any age; ii) two affected family members with breast or ovarian cancer with at least one of the cancers diagnosed before the age of 50 , or one male breast 
Table 1. BRCA1 and BRCA2 mutations identified in 64 breast cancer families from Northern Poland.

\begin{tabular}{|c|c|c|c|c|c|c|c|c|c|c|}
\hline \multirow[b]{2}{*}{ No. } & \multirow[b]{2}{*}{$\begin{array}{c}\text { Exon } \\
\text { no. }\end{array}$} & \multicolumn{2}{|c|}{$\begin{array}{l}\text { Nomenclature } \\
\text { comonly used }\end{array}$} & \multicolumn{2}{|c|}{$\begin{array}{c}\text { HGV } \\
\text { nomenclature [22] }\end{array}$} & \multirow[b]{2}{*}{$\begin{array}{c}\text { Mutation } \\
\text { type }^{b}\end{array}$} & \multirow[b]{2}{*}{$\begin{array}{c}\text { Mutation } \\
\text { status }\end{array}$} & \multirow[b]{2}{*}{$\begin{array}{c}\text { Proband } \\
\text { status (age) }\end{array}$} & \multirow[b]{2}{*}{$\begin{array}{c}\text { Family } \\
\text { type }\end{array}$} & \multirow[b]{2}{*}{$\begin{array}{c}\text { Family } \\
\text { no. }\end{array}$} \\
\hline & & $\begin{array}{l}\text { Nucleotide } \\
\text { change }\end{array}$ & Effect & $\begin{array}{l}\text { Nucleotide } \\
\text { change }^{\mathrm{a}}\end{array}$ & Effect & & & & & \\
\hline \multicolumn{11}{|c|}{ BRCA1 } \\
\hline 1. & 2 & 185delAG & ter 39 & c.68_69delAG & p.E23fsX18 & $\mathrm{F}$ & Founder & $\mathrm{BC}(51)$ & $\begin{array}{l}\mathrm{BC} / \mathrm{OC} \\
\mathrm{OC}(51)\end{array}$ & 663 \\
\hline 2. & 2 & 185delAG & ter 39 & c.68_69delAG & p.E23fsX18 & $\mathrm{F}$ & Founder & $\mathrm{OC}(52)$ & $\mathrm{BC} / \mathrm{OC}$ & 779 \\
\hline 3. & 2 & 185delAG & ter 39 & c.68_69delAG & p.E23fsX18 & $\mathrm{F}$ & Founder & $\begin{array}{l}\mathrm{BC}(43) \\
\mathrm{OC}(50)\end{array}$ & $\mathrm{BC} / \mathrm{OC}$ & 681 \\
\hline 4. & 5 & $300 \mathrm{~T}>\mathrm{G}$ & Cys61Gly & c. $181 \mathrm{~T}>\mathrm{G}$ & p.C61G & M & Founder & BC (32) & $\mathrm{BC}$ & 671 \\
\hline 5. & 5 & $300 \mathrm{~T}>\mathrm{G}$ & Cys61Gly & c. $181 \mathrm{~T}>\mathrm{G}$ & p.C61G & M & Founder & OC (43) & $\mathrm{BC} / \mathrm{OC}$ & 696 \\
\hline 6. & 5 & $300 \mathrm{~T}>\mathrm{G}$ & Cys61Gly & c. $181 \mathrm{~T}>\mathrm{G}$ & p.C61G & M & Founder & $\begin{array}{l}\mathrm{BC}(37) \\
\mathrm{OC}(44)\end{array}$ & $\mathrm{BC} / \mathrm{OC}$ & 906 \\
\hline 7. & 5 & $300 \mathrm{~T}>\mathrm{G}$ & Cys61Gly & c. $181 \mathrm{~T}>\mathrm{G}$ & p.C61G & M & Founder & $\begin{array}{l}\mathrm{BC}(43) \\
\mathrm{OC}(55)\end{array}$ & $\mathrm{BC} / \mathrm{OC}$ & 1017 \\
\hline 8. & 5 & $300 \mathrm{~T}>\mathrm{G}$ & Cys61Gly & c. $181 \mathrm{~T}>\mathrm{G}$ & p.C61G & M & Founder & BC (39) & $\mathrm{BC}$ & 1058 \\
\hline 9. & 5 & $300 \mathrm{~T}>\mathrm{G}$ & Cys61Gly & c. $181 \mathrm{~T}>\mathrm{G}$ & p.C61G & M & Founder & OC (54) & $\mathrm{BC} / \mathrm{OC}$ & 1145 \\
\hline 10. & 5 & $300 \mathrm{~T}>\mathrm{G}$ & Cys61Gly & c. $181 \mathrm{~T}>\mathrm{G}$ & p.C61G & M & Founder & $\mathrm{BC}(48)$ & $\mathrm{BC}$ & 1267 \\
\hline 11. & 5 & $300 \mathrm{~T}>\mathrm{G}$ & Cys61Gly & c. $181 \mathrm{~T}>\mathrm{G}$ & p.C61G & M & Founder & $\begin{array}{l}\text { BC (38) } \\
\text { BC (43) } \\
\text { OC (47) }\end{array}$ & $\mathrm{BC} / \mathrm{OC}$ & 1280 \\
\hline 12. & 5 & $300 \mathrm{~T}>\mathrm{G}$ & Cys61Gly & c. $181 \mathrm{~T}>\mathrm{G}$ & p.C61G & M & Founder & $\mathrm{BC}(52)$ & $\mathrm{BC} / \mathrm{OC}$ & 1764 \\
\hline 13. & 11 & 2991del5 & ter 969 & c.2872_2876del5 & p.F958_R959delinsRfsX12 & $\mathrm{F}$ & Novel & $\begin{array}{l}\mathrm{BC}(37) \\
\mathrm{OC}(43)\end{array}$ & $\mathrm{BC} / \mathrm{OC}$ & 1064 \\
\hline 14. & 11 & 3819del5 & ter 1242 & c.3700_3704del5 & p.V1234_N1235delinsQfsX9 & $\mathrm{F}$ & Recurrent & UA & $\mathrm{BC}$ & 705 \\
\hline 15. & 11 & 3819del5 & ter 1242 & c.3700_3704del5 & p.V1234_N1235delinsQfsX9 & $\mathrm{F}$ & Recurrent & UA & $\mathrm{BC}$ & 1150 \\
\hline 16. & 11 & 3819del5 & ter 1242 & c.3700_3704del5 & p.V1234_N1235delinsQfsX9 & $\mathrm{F}$ & Recurrent & UA & $\mathrm{BC}$ & 1262 \\
\hline 17. & 11 & 3819del5 & ter 1242 & c.3700_3704del5 & p.V1234_N1235delinsQfsX9 & $\mathrm{F}$ & Recurrent & $\mathrm{OC}(47)$ & $\mathrm{BC} / \mathrm{OC}$ & 1763 \\
\hline 18. & 11 & $3936 \mathrm{C}>\mathrm{T}$ & Gln1273Stop & c. $3817 \mathrm{C}>\mathrm{T}$ & p.G1273X & $\mathrm{N}$ & $\mathrm{BIC}(2)^{\mathrm{d}}$ & UA & $\mathrm{BC}$ & 1522 \\
\hline 19. & 20 & 5382 insC & ter 1829 & c.5266dupC & p.Q1756fsX74 & $\mathrm{F}$ & Founder & OC (49) & $\mathrm{BC} / \mathrm{OC}$ & 673 \\
\hline 20. & 20 & 5382 insC & ter 1829 & c.5266dupC & p.Q1756fsX74 & $\mathrm{F}$ & Founder & OC (58) & $\mathrm{BC} / \mathrm{OC}$ & 718 \\
\hline 21. & 20 & 5382insC & ter 1829 & c.5266dupC & p.Q1756fsX74 & $\mathrm{F}$ & Founder & $\begin{array}{l}\mathrm{BC}(53) \\
\mathrm{OC}(53)\end{array}$ & $\mathrm{BC} / \mathrm{OC}$ & 723 \\
\hline 22. & 20 & 5382 insC & ter 1829 & c.5266dupC & p.Q1756fsX74 & $\mathrm{F}$ & Founder & OC (48) & $\mathrm{BC} / \mathrm{OC}$ & 734 \\
\hline 23. & 20 & 5382 insC & ter 1829 & c.5266dupC & p.Q1756fsX74 & $\mathrm{F}$ & Founder & $\mathrm{OC}(51)$ & $\mathrm{BC} / \mathrm{OC}$ & 782 \\
\hline 24. & 20 & 5382 insC & ter 1829 & c.5266dupC & p.Q1756fsX74 & $\mathrm{F}$ & Founder & BC (43) & $\mathrm{BC}$ & 819 \\
\hline 25. & 20 & 5382 insC & ter 1829 & c.5266dupC & p.Q1756fsX74 & $\mathrm{F}$ & Founder & BC (48) & $\mathrm{BC}$ & 839 \\
\hline 26. & 20 & 5382 insC & ter 1829 & c.5266dupC & p.Q1756fsX74 & $\mathrm{F}$ & Founder & OC (47) & $\mathrm{BC} / \mathrm{OC}$ & 876 \\
\hline 27. & 20 & 5382insC & ter 1829 & c.5266dupC & p.Q1756fsX74 & $\mathrm{F}$ & Founder & $\begin{array}{l}\mathrm{BC}(48) \\
\mathrm{OC}(56)\end{array}$ & $\mathrm{BC} / \mathrm{OC}$ & 903 \\
\hline 28. & 20 & 5382insC & ter 1829 & c.5266dupC & p.Q1756fsX74 & $\mathrm{F}$ & Founder & $\begin{array}{l}\mathrm{BC}(49) \\
\mathrm{OC}(51)\end{array}$ & $\mathrm{BC} / \mathrm{OC}$ & 908 \\
\hline 29. & 20 & 5382insC & ter 1829 & c.5266dupC & p.Q1756fsX74 & $\mathrm{F}$ & Founder & $\begin{array}{l}\mathrm{BC}(50) \\
\mathrm{OC}(51)\end{array}$ & $\mathrm{BC} / \mathrm{OC}$ & 910 \\
\hline 30. & 20 & 5382 insC & ter 1829 & c.5266dupC & p.Q1756fsX74 & $\mathrm{F}$ & Founder & $\begin{array}{l}\mathrm{BC}(49) \\
\mathrm{OC}(46)\end{array}$ & $\mathrm{BC} / \mathrm{OC}$ & 949 \\
\hline 31. & 20 & 5382 insC & ter 1829 & c.5266dupC & p.Q1756fsX74 & $\mathrm{F}$ & Founder & OC (44) & $\mathrm{BC} / \mathrm{OC}$ & 973 \\
\hline 32. & 20 & 5382 insC & ter 1829 & c.5266dupC & p.Q1756fsX74 & $\mathrm{F}$ & Founder & BC (40) & $\mathrm{BC}$ & 990 \\
\hline 33. & 20 & 5382insC & ter 1829 & c.5266dupC & p.Q1756fsX74 & $\mathrm{F}$ & Founder & $\begin{array}{l}\mathrm{BC}(47) \\
\mathrm{BC}(66)\end{array}$ & $\mathrm{BC}$ & 1004 \\
\hline 34. & 20 & 5382 insC & ter 1829 & c.5266dupC & p.Q1756fsX74 & $\mathrm{F}$ & Founder & $\mathrm{BC}(45)$ & $\mathrm{BC}$ & 1131 \\
\hline
\end{tabular}


Table 1. Continued.

\begin{tabular}{|c|c|c|c|c|c|c|c|c|c|c|}
\hline \multirow[b]{2}{*}{ No. } & \multirow[b]{2}{*}{$\begin{array}{c}\text { Exon } \\
\text { no. }\end{array}$} & \multicolumn{2}{|c|}{$\begin{array}{l}\text { Nomenclature } \\
\text { comonly used }\end{array}$} & \multicolumn{2}{|c|}{$\begin{array}{c}\text { HGV } \\
\text { nomenclature [22] }\end{array}$} & \multirow[b]{2}{*}{$\begin{array}{l}\text { Mutation } \\
\text { type }^{\mathrm{b}}\end{array}$} & \multirow[b]{2}{*}{$\begin{array}{l}\text { Mutation } \\
\text { status }\end{array}$} & \multirow[b]{2}{*}{$\begin{array}{c}\text { Proband } \\
\text { status (age) }\end{array}$} & \multirow[b]{2}{*}{$\begin{array}{l}\text { Family } \\
\text { type }\end{array}$} & \multirow[b]{2}{*}{$\begin{array}{c}\text { Family } \\
\text { no. }\end{array}$} \\
\hline & & $\begin{array}{l}\text { Nucleotide } \\
\text { change }\end{array}$ & Effect & $\begin{array}{l}\text { Nucleotide } \\
\text { change }^{\mathrm{a}}\end{array}$ & Effect & & & & & \\
\hline 35. & 20 & 5382 insC & ter 1829 & c.5266dupC & p.Q1756fsX74 & $\mathrm{F}$ & Founder & BC (26) & $\mathrm{BC}$ & 1154 \\
\hline 36. & 20 & 5382insC & ter 1829 & c.5266dupC & p.Q1756fsX74 & $\mathrm{F}$ & Founder & BC (33) & $\mathrm{BC}$ & 1197 \\
\hline 37. & 20 & 5382insC & ter 1829 & c.5266dupC & p.Q1756fsX74 & $\mathrm{F}$ & Founder & UA & $\mathrm{BC}$ & 1250 \\
\hline 38. & 20 & 5382insC & ter 1829 & c.5266dupC & p.Q1756fsX74 & $\mathrm{F}$ & Founder & BC (33) & $\mathrm{BC}$ & 1306 \\
\hline 39. & 20 & $5382 \mathrm{insC}$ & ter 1829 & c.5266dupC & p.Q1756fsX74 & $\mathrm{F}$ & Founder & UA & $\mathrm{BC} / \mathrm{OC}$ & 1637 \\
\hline \multicolumn{11}{|c|}{ BRCA2 } \\
\hline 40. & 11 & 6238ins2del21 & ter 2033 & $\begin{array}{c}\text { c.6010_6030delins } \\
\text { TT }\end{array}$ & $\begin{array}{l}\text { p.E2004_V2010del } \\
\text { insfsX36 }\end{array}$ & $\mathrm{F}$ & Novel & BC (42) & $\mathrm{BC}$ & 703 \\
\hline 41. & 21 & 8876delC & ter 2890 & c.8648delC & p.P2883fsX8 & $\mathrm{F}$ & Novel & BC (40) & $\mathrm{BC}$ & 832 \\
\hline 42. & 27 & 10323delCins11 & ter 3369 & c.10095delCins 11 & p.V3365fsX5 & UV & Recurrent & $\mathrm{OC}(54)$ & $\mathrm{BC} / \mathrm{OC}$ & 21 \\
\hline 43. & 27 & 10323delCins11 & ter 3369 & c.10095delCins11 & p.V3365fsX5 & UV & Recurrent & $\mathrm{OC}(51)$ & $\mathrm{BC} / \mathrm{OC}$ & 907 \\
\hline \multicolumn{11}{|c|}{ Large rearrangements } \\
\hline 44. & $\begin{array}{r}1 \mathrm{~A} \\
1 \mathrm{~B} \\
2\end{array}$ & $\operatorname{del1A-2}$ & & c.-184-?_80+?del & p. $0 ?$ & $\mathrm{~F}$ & Novel? & BC (39) & $\mathrm{BC}$ & $\mathrm{Si}-18$ \\
\hline 45. & $\begin{array}{l}17 \\
18 \\
19\end{array}$ & del17-19 & & c.4987-?_5193+?del & p.M1663_E1731del & $\mathrm{F}$ & Novel? & $\begin{array}{l}\text { BC (33) } \\
\text { BC (41) } \\
\text { CC (50) }\end{array}$ & $\mathrm{BC}$ & 1006 \\
\hline
\end{tabular}

${ }^{a}$ Nucleotide +1 is the $\mathrm{A}$ of the translation initiation codon. ${ }^{\mathrm{b}} \mathrm{F}$, frameshift; $\mathrm{M}$, missense; $\mathrm{N}$, nonsense. ${ }^{\mathrm{c}} \mathrm{BC}$, breast cancer; $\mathrm{CC}$, colon cancer; OC, ovarian

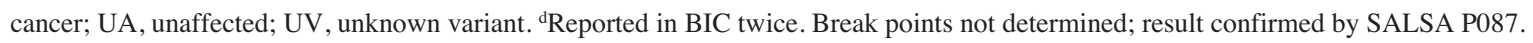

cancer; iii) one family member affected with both breast and ovarian cancer.

Of the 124 breast/ovarian cancer families found so far, 80 are site-specific breast cancer families, two including male breast cancer, 41 are breast/ovarian cancer families and three are site-specific ovarian cancer families. The average age at diagnosis of breast cancer was 47 years (range 27-70) and of ovarian cancer 47 (29-73) years, respectively.

Out of the 124 families, 60 were previously screened for mutations in BRCA1/2 genes (3). Here, we present the results of BRCA1/2 mutation screening in the 64 most recently sampled patients, and also the results of large rearrangements testing in a group of 43 BRCA1/2-negative families selected from the combined set of 124 families.

Samples. DNA was extracted from the whole blood. Red blood cells were lysed by red blood cell lysis buffer. The leucocytes were isolated and then digested by adding $5 \mathrm{ml}$ of $75 \mathrm{mM} \mathrm{NaCl} / 1 \mathrm{mM}$ EDTA buffer, $500 \mathrm{ml}$ of $10 \% \mathrm{SDS}$ and $12 \mathrm{ml}$ of $20 \mathrm{mg} / \mathrm{ml}$ proteinase $\mathrm{K}$ to this solution. DNA was extracted by standard phenol-chloroform procedures.

Screening for BRCA1 and BRCA2 germline point mutations. In the 64 new breast/ovarian cancer families, the complete coding sequence of BRCA1 and BRCA2, including splice junctions, was amplified by PCR. Exon 11 of the BRCA1 gene was divided into 13 fragments. Similarly, exons 10 and 11 of the BRCA2 gene were divided into 5 and 19 fragments, respectively.

Mutational analysis was carried out by pre-screening using the DHPLC technique (WAVE DNA Fragment Analysis System, Transgenomic Inc., San Jose, CA, USA). Fragments showing elution profiles distinct from those of the wild-type samples were subsequently sequenced to determine the exact sequence alterations. More information on screening protocols, including the choice of primers, can be obtained from the corresponding author upon request.

MLPA analysis. Of the 124 families from the combined series, 65 tested negative according to our conventional BRCA1/2 screening. Forty-three of the 65 , manifesting strong breast and/or ovarian cancer family history, were eligible for extended screening. Multiplex Ligation-dependent PCR Amplification (MLPA) was carried out using the following kits: P002_BRCA1, P045_BRCA2, complemented by P087_BRCA1 to confirm different peak patterns of P002_BRCA1 (MRC Holland, The Netherlands). The MLPA reaction was performed as instructed by the manufacturer. 
Fragment analysis was carried out on the ABI PRISM ${ }^{\circledast} 310$ Genetic Analyzer (Applied Biosystems, USA) using TAMRA500 (Applied Biosystems) as a size standard. A peak pattern was characteristic for each of the mentioned MLPA kits.

For statistical analysis, the raw data of each individual exon peak area were transferred to an Excel data sheet (Microsoft, Redmond, USA). All exons were normalised by dividing each peak area by the combined area of all the peaks in the sample (relative peak area, RPA). Samples with standard deviation above $15 \%$ were excluded from further statistical analysis and MLPA reaction was repeated. RPA ratios of individual exons were compared to the average results obtained on all samples. Results were considered indicative of exon(s) deletion when the RPA for that probe amplification product was reduced to $35-50 \%$, and indicative of duplication by the increase of RPA to above $135-150 \%$.

\section{Results}

In the 64 new families we found 43 mutations (67\%) (Table 1). In accordance with our previous study, the most frequent mutations were BRCA1 5382insC (found in 22 of the 43 BRCA families; $51 \%$ ) and Cys61Gly (9/43; 20\%). Other identified recurrent mutations were $185 \mathrm{delAG}(\mathrm{n}=3 ; 7 \%)$ and $3819 \operatorname{del} 5(n=4 ; 9 \%)$. Apart from these mutations, six different pathogenic sequence alterations, each in single families, and two unknown deleterious variants in BRCA2 gene were found (Table 1).

The novel BRCA1 2991del5 mutation was identified in a breast/ovarian cancer family (no. 1064) in which the index case was affected by both breast cancer (at the age of 37 years) and ovarian cancer (43 years). The mutation is located in exon 11 and results in premature termination (stop codon in position 969). The novel BRCA2 6238ins2del21 mutation was identified in a site-specific breast cancer family (no. 703) where the index (diagnosed at the age of 42 years), her mother (40) and her maternal aunt (42) were all affected by breast cancer (Fig. 1). Another BRCA2 mutation (8876delC) was identified in a breast/ovarian cancer family (no. 832) which included three breast cancer cases affected at the age of $\sim 40$ years and one ovarian cancer case diagnosed at 66 years.

The unknown variant 10323delCins11, which was identified in two breast/ovarian families (nos. 21 and 907), results in premature termination of translation at position 3369 in the very carboxy terminal of BRCA2. Both index cases were affected by ovarian cancer, at the ages of 54 and 51 , respectively. In both families, there was a strong genetic background of the disease including, in one case, male breast cancer (Fig 2). Sampling of other affected family members for segregation analysis was not possible.

Finally, MLPA analysis showed two large rearrangements within the BRCA1 gene. In one family (Si-18), abnormal RPA ratio was detected for exons $1 \mathrm{~A}(60 \%), 1 \mathrm{~B}(60 \%)$ and $2(66 \%)$, indicative of a large deletion of these exons. In the second family (no. 1006), abnormal RPA ratio was detected for exons $17(35 \%), 18(33 \%)$ and $19(36 \%)$, suggestive of a deletion of these three exons (Fig. 3A). Both results were confirmed with another SALSA Kit - P087 (Fig. 3B). Because of the lack of material from these patients, it was not possibile to perform breakpoint analysis.
A

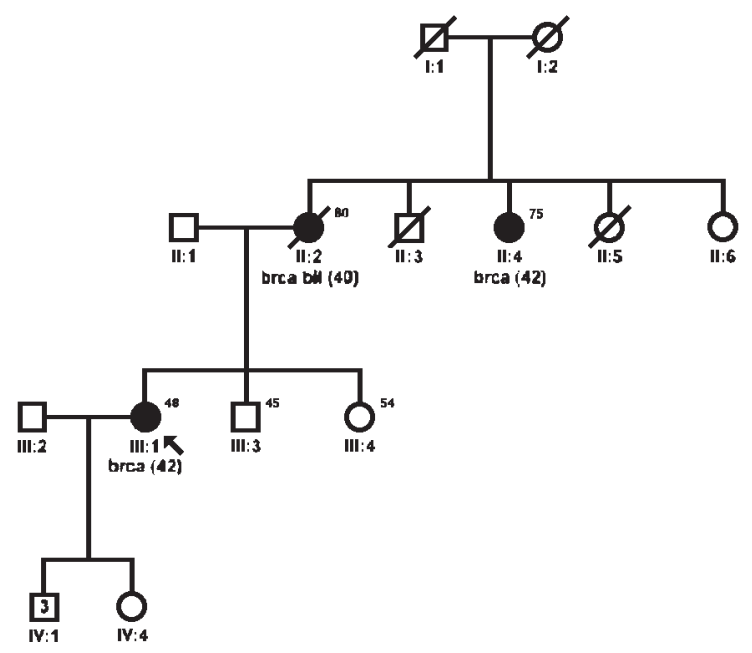

B

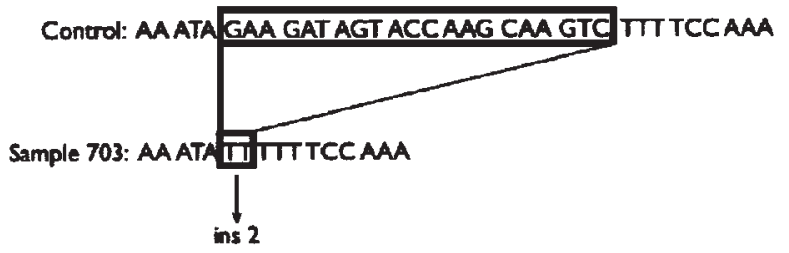

Figure 1. (A) Pedigree of family no. 703 carrying the novel BRCA2 6238ins2del21 mutation. $\rightarrow$, proband; brca, breast cancer; brca bil, bilateral breast cancer; (42), age at diagnosis; /, dead. (B) Schematic representation of the fragment of BRCA2 gene which is deleted.

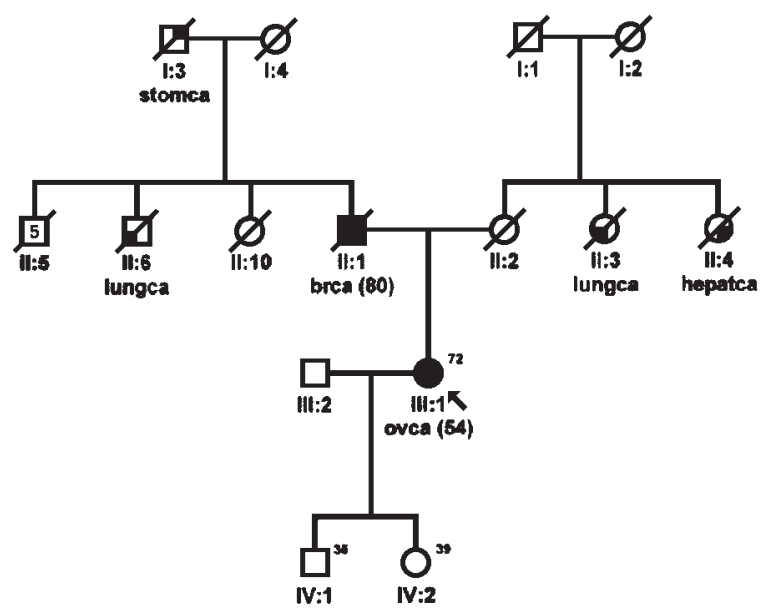

Figure 2. Pedigree of family no. 21 carrying the BRCA2 10323delCins 11 unknown variant. $\rightarrow$, proband; (54), age at diagnosis; /, dead.

\section{Discussion}

The present study of 64 breast and/or ovarian cancer families demonstrates an unusually high frequency $(43 / 64,67 \%)$ of confirmed or suspected deleterious BRCA1/2 mutations. This is higher compared to previous studies performed on Polish families (range 32-53\%) (3-7) and may be caused by differences in family inclusion criteria, screening method strategy or sensitivity, or just by random variation in small materials. The mutation frequency in our combined material is $48 \%$ $(59 / 124)$, which is still very high and approaches findings in 
A
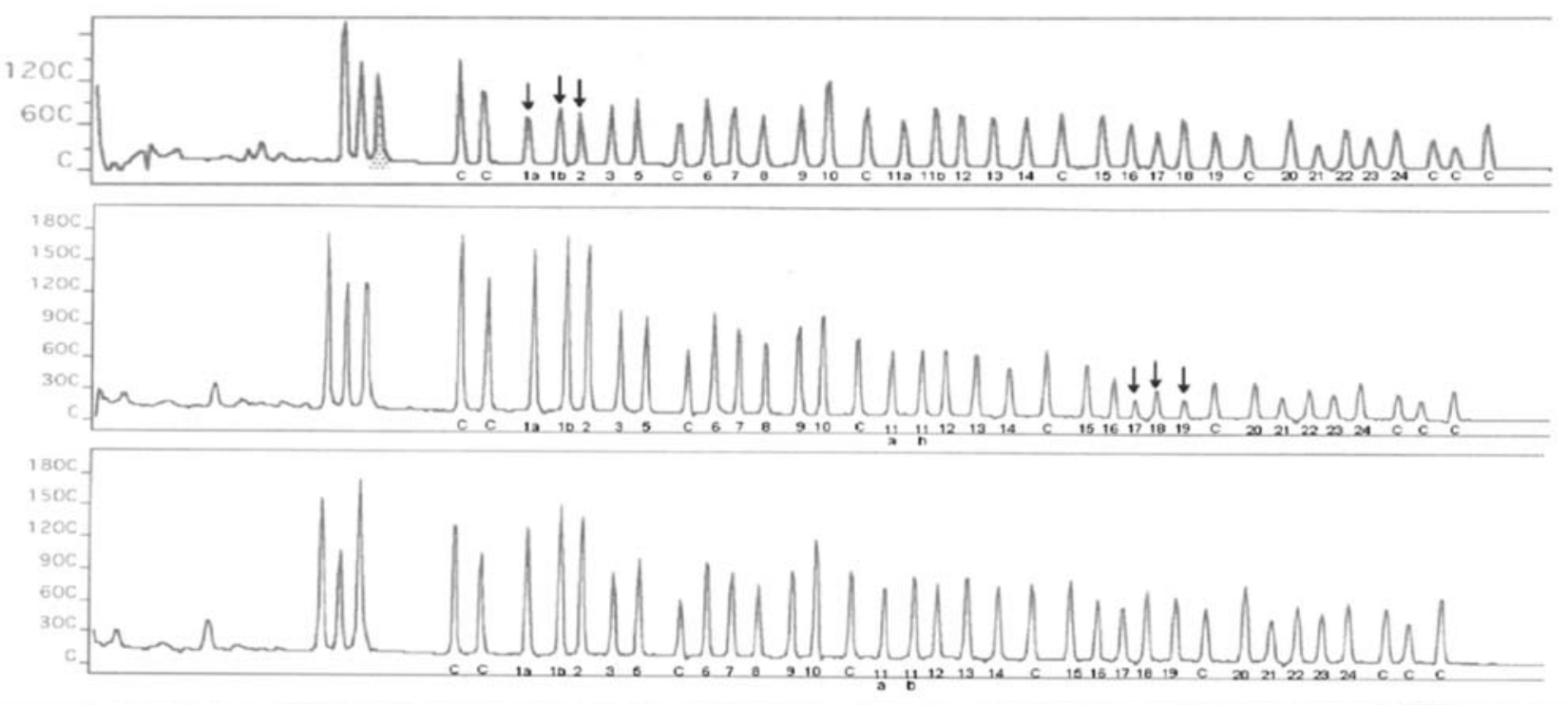

$\mathbf{B}$
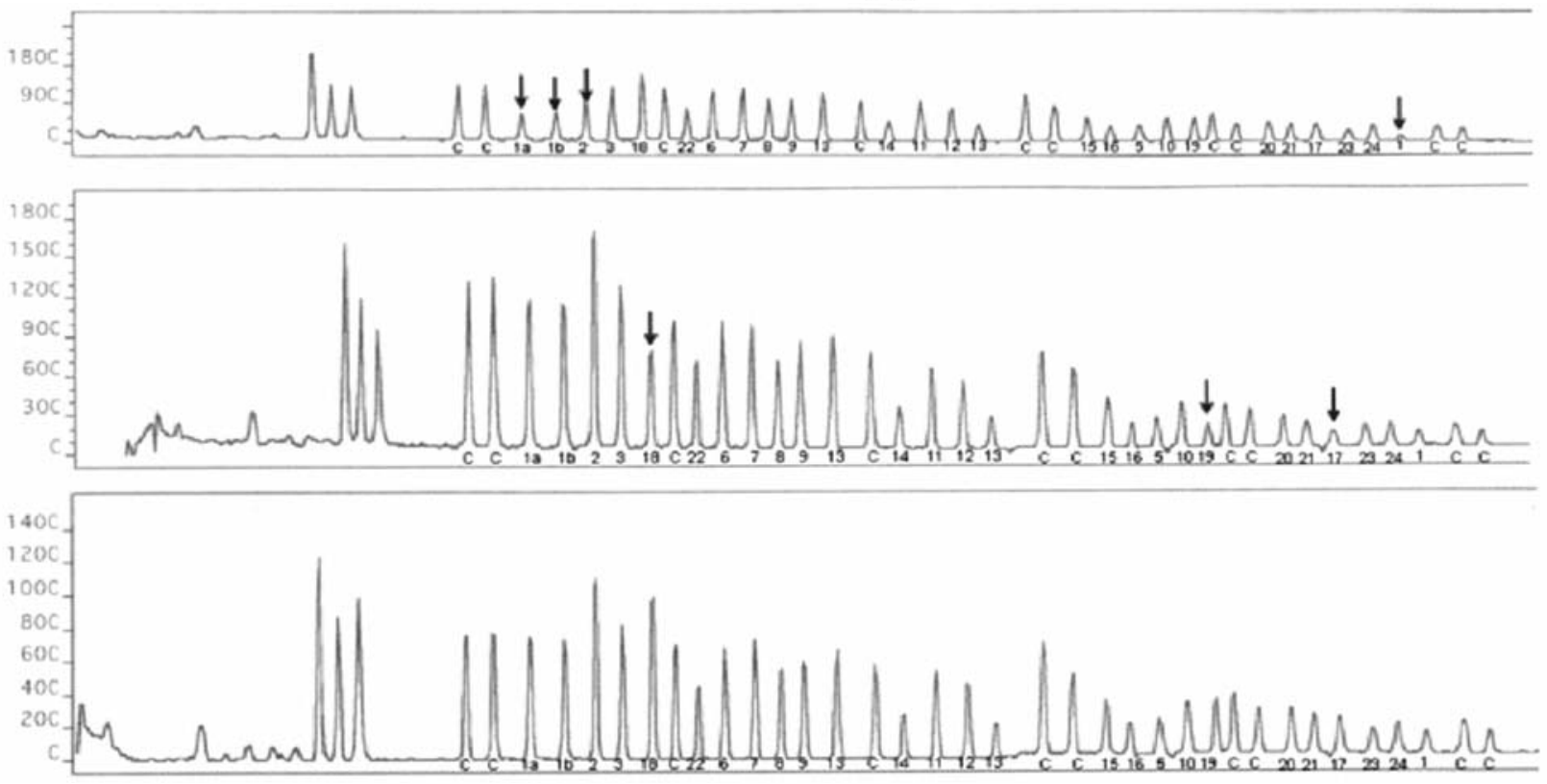

Figure 3. Electropherograms in normal and abnormal samples. (A) MLPA Kit - SALSA P002; (B) MLPA Kit - SALSA P087. Samples are compared to controls. Each peak represents one BRCA1 exon. Note the decreased peak heights of exons 1A, 1B, 2 and 17, 18, 19 in Figs. 3A and B, respectively, as compared to the controls.

other populations with strong founder effects, such as Iceland and Norway $(8,9)$.

We confirm the dominance of two global BRCA1 founder mutations (5382insC, Cys61Gly), which account for more than $70 \%$ of all mutations identified in this series. This is largely in agreement with our previous study and with other investigations performed with Polish families (3-7). Moreover, by adding two other recurring BRCA1 mutations (185delAG and 3819 del5), the vast majority $(87 \%)$ of mutation-positive families in our material is encompassed by this foursome. We have now described a total of 15 distinct mutations in our material and emphasise our previous conclusions, that the mutation spectrum in Northern Poland is as diverse as in other populations and more dispersed than previously suggested (4).

An unclassified variant (10323delCins11 in BRCA2), reported several times in BIC, was identified in two of our patients, both negative for other point mutations in BRCA1 and BRCA2 genes and for large rearrangements. This variant is predicted to introduce a stop codon in position 3369 , truncating the BRCA2 protein by merely 49 amino acids and positioned even closer to the carboxy terminus than a previously described common variant and suggested polymorphic stop codon, Lys3326Stop (10). It has been implied that the $\mathrm{C}$-terminal of the BRCA2 protein is functionally dispensable and that truncating mutations in the 3 '-end of BRCA2 should be carefully interpreted and not used for predictive testing. However, this was recently challenged by findings indicating a possibly higher risk of pancreas cancer in K3326X carriers (11), and also by the pedigrees of the present two 10323delCins 11 families. The presence of male breast cancer in one of these families substantiates a BRCA2 background for the disease. Based on this observation, we propose that 10323 delCins 11 should be regarded as possibly functionally damaging and further scrutinised by segregation and population analysis before being introduced to oncogenetic counselling.

This study is the first to describe the presence of large BRCA1 rearrangements in Polish families. The past few years 
have brought great advances in understanding the mechanisms, besides point mutations, leading to the inactivation of BRCA1 and BRCA2 (12). The first reported large BRCA1 rearrangement was found in an American family (13). Since then, many groups have searched for large deletions and duplications among patients who were previously found to be negative for BRCA1/2 point mutations. This strategy has resulted in an ever-growing number of identified rearrangements, the vast majority affecting BRCA1 (14-17). The frequencies of such alterations vary between populations and may account for as much as $30-36 \%$ of all BRCA1 mutations, as reported in Dutch and Italian populations $(18,19)$.

Here, we demonstrate two presumably novel large BRCA1 deletions in 2 of 43 previously BRCA mutation-negative families. One affects the 5'-end of BRCA1, covering exons 1A, $1 \mathrm{~B}$ and 2 , and extends for a still unknown distance into the promoter region and possibly the pseudogene $\psi$ BRCA1 located $28 \mathrm{~kb}$ upstream of BRCA1 (20). The second deletion spans BRCA1 exons 17-19, covering a genomic region of approximately $11 \mathrm{~kb}$ as confirmed by diagnostic primers (Forward: 5'-TATGTATCTCCCTAATGACTAAGAC-3', Reverse: 5'-GGAGCAGACACGTCATATTTAAGG-3'). A similar frequency (3\%) was observed in the German population (16), implying that although large BRCA1 rearrangements characterise familial breast cancer in Poland and its geographical vicinity as well, there is probably no strong founder effect for such mutations in our population.

Given the strong founder effect but still diverse spectrum of BRCA1/2 mutations in our region, we postulate the following testing strategy for breast cancer families from Poland: Stage 1, screening for the presence of BRCA1 founder and frequently recurrent mutations. Stage 2, for negative patients with a strong family history, screening of the complete coding sequence of BRCA1 and BRCA2. Stage 3, if point mutations are excluded, continued screening for large rearrangements in BRCA1 and BRCA2. Due to the heterogeneity of our population, limiting genetic testing to the most common BRCA1/2 founder mutations will result in some BRCA positive families being missed. Our results indicate the necessity for extended analysis among patients negative for BRCA1/2 founder mutations.

\section{Acknowledgements}

This study was supported by a grant from MNiSW: N401 $16431 / 3656$.

\section{References}

1. Breast Cancer Information Core: http://research.nhgri.nih.gov/bic/

2. Unger MA, Nathanson KL, Calzone K, Antin-Ozerkis D, Shih HA, Martin AM, Lenoir GM, Mazoyer S and Weber BL: Screening for genomic rearrangements in families with breast and ovarian cancer identifies BRCA1 mutations previously missed by conformation-sensitive gel electrophoresis or sequencing. Am J Hum Genet 67: 841-850, 2000.

3. Perkowska M, Brozek I, Wysocka B, Haraldsson K, Sandberg T, Johansson U, Sellberg G, Borg A and Limon J: BRCA1 and BRCA2 Mutation Analysis in Breast-Ovarian Cancer Families From Northeastern Poland. Hum Mutat 21: 553-554, 2003.

4. Gorski B, Byrski T, Huzarski T, Jakubowska A, Menkiszak J, Gronwald J, Pluzanska A, Bebenek M, Fischer-Maliszewska L, Grzybowska E, Narod SA and Lubinski J: Founder mutations in the BRCA1 gene in Polish families with breast-ovarian cancer. Am J Hum Genet 66: 1963-1968, 2000.

5. Van der Looij M, Wysocka B, Brozek I, Jassem J, Limon J and Olah E: Founder BRCA1 mutations and two novel germline
BRCA2 mutations in breast and/or ovarian cancer families from north-eastern Poland. Hum Mutat 15: 480-481, 2000.

6. Grzybowska E, Zientek H , Jasinska A, Rusin M, Kozlowski P, Sobczak K, Sikorska A, Kwiatkowska E, Gorniak L, Kalinowska E, Utracka-Hutka B, Wloch J, Chmielik E and Krzyzosiak WJ: High frequency of recurrent mutations in BRCA1 and BRCA2 genes in Polish families with breast and ovarian cancer. Hum Mutat 16: 482-490, 2000.

7. Jakubowska A, Gorski B, Byrski T, Huzarski T, Gronwald J, Menkiszak J, Cybulski C, Debniak T, Hadaczek P, Scott RJ and Lubinski J: Detection of germline mutations in the BRCA1 gene by RNA-based sequencing. Hum Mutat 18: 149-156, 2001.

8. Moller P, Borg A, Heimdal K, Apold J, Vallon-Christersson J, Hovig E and Maehle L, Norwegian Inherited Breast Cancer Group, Norwegian Inherited Ovarian Cancer Group: The BRCA1 syndrome and other inherited breast or breast-ovarian cancers in a Norwegian prospective series. Eur J Cancer 37: 1027-1032, 2001.

9. Gudmundsson J, Johannesdottir G, Arason A, Bergthorsson JT, Ingvarsson S, Egilsson V and Barkardottir RB: Frequent occurrence of BRCA2 linkage in Icelandic breast cancer families and segregation of a common BRCA2 haplotype. Am J Hum Genet 58: 749-756, 1996.

10. Mazoyer S, Dunning AM, Serova O, Dearden J, Puget N, Healey CS, Gayther SA, Mangion J, Stratton MR, Lynch HT, Goldgar DE, Ponder BA and Lenoir GM: A polymorphic stop codon in BRCA2. Nat Genet 14: 253-254, 1996.

11. Martin ST, Matsubayashi H, Rogers CD, Philips J, Couch FJ, Brune K, Yeo CJ, Kern SE, Hruban RH and Goggins M: Increased prevalence of the BRCA2 polymorphic stop codon K3326X among individuals with familial pancreatic cancer. Oncogene 24: 3652-3656, 2005.

12. Mazoyer S: Genomic Rearrangements in the BRCA1 and BRCA2 Genes. Hum Mutat, 25: 415-422, 2005.

13. Puget N, Torchard D, Serova-Sinilnikova OM, Lynch HT, Feunteun J, Lenoir GM and Mazoyer S: A 1-kb Alu-mediated germ-line deletion removing BRCA1 exon 17. Cancer Res 57: 828-831, 1997.

14. Hogervorst FB, Nederlof PM, Gille JJ, McElgunn CJ, Grippeling M, Pruntel R, Regnerus R, van Welsem T, van Spaendonk R, Menko FH, Kluijt I, Dommering C, Verhoef S, Schouten JP, van't Veer LJ and Pals G: Large genomic deletions and duplications in the BRCA1 gene identified by a novel quantitative method. Cancer Res 63: 1449-1453, 2003.

15. Belogianni I, Apessos A, Mihalatos M, Razi E, Labropoulos S, Petounis A, Gaki V, Keramopoulos A, Pandis N, Kyriacou K, Hadjisavvas A, Kosmidis P, Yannoukakos D and Nasioulas G: Characterization of a novel large deletion and single point mutations in the BRCA1 gene in a Greek cohort of families with suspected hereditary breast cancer. BMC Cancer 7: 61, 2004.

16. Hartmann C, John AL, Klaes R, Hofmann W, Bielen R, Koehler R, Janssen B, Bartram CR, Arnold N and Zschocke J: Large BRCA1 gene deletions are found in 3\% of German highrisk breast cancer families. Hum Mutat 24: 534, 2004.

17. Walsh T, Casadei S, Coats KH, Swisher E, Stray SM, Higgins J, Roach KC, Mandell J, Lee MK, Ciernikova S, Foretova L, Soucek P and King MC: Spectrum of mutations in BRCA1, BRCA2, CHEK2, and TP53 in families at high risk of breast cancer. JAMA 295: 1379-1388, 2006.

18. Petrij-Bosch A, Peelen T, van Vliet M, van Eijk R, Olmer R, Drusedau M, Hogervorst FB, Hageman S, Arts PJ, Ligtenberg MJ, Meijers-Heijboer H, Klijn JG, Vasen HF, Cornelisse CJ, van't Veer LJ, Bakker E, van Ommen GJ and Devilee P: BRCA1 genomic deletions are major founder mutations in Dutch breast cancer patients. Nat Genet 17: 341-345, 1997.

19. Montagna M, Dalla Palma M, Menin C, Agata S, De Nicolo A, Chieco-Bianchi L and D'Andrea E: Genomic rearrangements account for more than one-third of the BRCA1 mutations in northern Italian breast/ovarian cancer families. Hum Mol Genet 12: 1055-1061, 2003.

20. Puget N, Gad S, Perrin-Vidoz L, Sinilnikova OM, StoppaLyonnet D, Lenoir GM and Mazoyer S: Distinct BRCA1 rearrangements involving the BRCA1 pseudogene suggest the existence of a recombination hot spot. Am J Hum Genet 70: 858-865, 2002

21. Den Dunnen JT and Antonarakis SE. Mutation nomenclature extensions and suggestions to describe complex mutations: A discussion. Hum Mutat 15: 7-12, 2000.

22. Nomenclature for the description of sequence variations: http:// www.hgvs.org/mutnomen/ 